\title{
Business Takeover or New Venture? Individual and Environmental Determinants from a Cross-Country Study
}

\author{
Joern Block, Roy Thurik, Peter Van der Zwan, and Sascha Walter
}

February 2012 Version

\begin{tabular}{|l|l|}
\hline \multicolumn{2}{|l|}{ ERIM REPORT SERIES RESEARCH IN MANAGEMENT } \\
\hline ERIM Report Series reference number & ERS-2010-042-ORG \\
\hline Publication & February 20122 \\
\hline Number of pages & 23 \\
\hline Persistent paper URL & http://hdl.handle.net/1765/21239 \\
\hline Email address corresponding author & block@ese.eur.nl \\
\hline Address & Erasmus Research Institute of Management (ERIM) \\
& RSM Erasmus University / Erasmus School of Economics \\
& Erasmus Universiteit Rotterdam \\
& P.O.Box 1738 \\
& 3000 DR Rotterdam, The Netherlands \\
& Phone: + 31104081182 \\
& Fax: $\quad+31104089640$ \\
& Email: info@erim.eur.nl \\
& Internet: $\quad$ www.erim.eur.nl \\
\hline
\end{tabular}

Bibliographic data and classifications of all the ERIM reports are also available on the ERIM website: www.erim.eur.nl 


\section{ERASMUS RESEARCH INSTITUTE OF MANAGEMENT}

\section{REPORT SERIES}

\section{RESEARCH IN MANAGEMENT}

\begin{tabular}{|c|c|}
\hline \multicolumn{2}{|c|}{ ABSTRACT AND KEYWORDS } \\
\hline Abstract & $\begin{array}{l}\text { Whereas the determinants of entrepreneurial choice have been thoroughly analyzed in the } \\
\text { literature, little is known about the preferred mode of entry into entrepreneurship, such as taking } \\
\text { over an existing business or starting a new venture. Using a large international dataset, this } \\
\text { study reports considerable differences in takeover preferences across } 33 \text { countries. Hierarchical } \\
\text { (multi-level) regressions are performed to explore individual-level and country-level determinants } \\
\text { of the preferred mode of entry. At the individual level, a person's human capital, risk attitude, and } \\
\text { inventiveness influence the preference for starting a new venture versus taking over an existing } \\
\text { business. At the country level, the culture-inherent level of risk tolerance, the country's level of } \\
\text { innovation output, and the administrative difficulty of starting a new business are found to explain } \\
\text { the between-country variation in the preferred mode of entry. Implications of our findings for } \\
\text { research and practice are also discussed. }\end{array}$ \\
\hline Free Keywords & $\begin{array}{l}\text { entrepreneurship, occupational choice, entry mode, business takeover, new venture start, } \\
\text { multi-level analysis }\end{array}$ \\
\hline Availability & $\begin{array}{l}\text { The ERIM Report Series is distributed through the following platforms: } \\
\text { Academic Repository at Erasmus University (DEAR), DEAR ERIM Series Portal } \\
\text { Social Science Research Network (SSRN), SSRN ERIM Series Webpage } \\
\text { Research Papers in Economics (REPEC), REPEC ERIM Series Webpage }\end{array}$ \\
\hline Classifications & $\begin{array}{l}\text { The electronic versions of the papers in the ERIM report Series contain bibliographic metadata } \\
\text { by the following classification systems: } \\
\text { Library of Congress Classification, (LCC) LCC Webpage } \\
\text { Journal of Economic Literature, (JEL), JEL Webpage } \\
\text { ACM Computing Classification System CCS Webpage } \\
\text { Inspec Classification scheme (ICS), ICS Webpage }\end{array}$ \\
\hline
\end{tabular}




\title{
Business takeover or new venture? Individual and environmental determinants from a cross-country study
}

\author{
Joern Block ${ }^{\mathrm{a}, \mathrm{b}}$, Roy Thurik ${ }^{\mathrm{b}, \mathrm{c}, \mathrm{e}}$, Peter Van der Zwan ${ }^{\mathrm{b}, \mathrm{c}}$, and \\ Sascha Walter ${ }^{\mathrm{d}}$ \\ ${ }^{a}$ Technische Universität München, München, Germany \\ block@wi.tum.de \\ ${ }^{\mathrm{b}}$ Centre for Advanced Small Business Economics, Erasmus School of Economics, \\ Erasmus University Rotterdam, P.O. Box 1738, 3000 DR Rotterdam, the Netherlands; Erasmus \\ Research Institute of Management (ERIM) \\ thurik@ese.eur.nl; vanderzwan@ese.eur.nl; block@ese.eur.nl \\ ${ }^{\mathrm{c}}$ Panteia/EIM Business and Policy Research, Zoetermeer, the Netherlands \\ ${ }^{\mathrm{d}}$ Christian-Albrechts-University Kiel, Germany \\ sascha.walter@,bwl.uni-kiel.de \\ ${ }^{\mathrm{e}}$ GSCM-Montpellier Business School, France
}

\begin{abstract}
Whereas the determinants of entrepreneurial choice have been thoroughly analyzed in the literature, little is known about the preferred mode of entry into entrepreneurship, such as taking over an existing business or starting a new venture. Using a large international dataset, this study reports considerable differences in takeover preferences across 33 countries. Hierarchical (multi-level) regressions are performed to explore individual-level and country-level determinants of the preferred mode of entry. At the individual level, a person's human capital, risk attitude, and inventiveness influence the preference for starting a new venture versus taking over an existing business. At the country level, the culture-inherent level of risk tolerance, the country's level of innovation output, and the administrative difficulty of starting a new business are found to explain the between-country variation in the preferred mode of entry. Implications of our findings for research and practice are also discussed.
\end{abstract}

JEL-codes: D01, L20, L26, M13

Keywords: entrepreneurship, occupational choice, entry mode, business takeover, new venture start, multi-level analysis

Acknowledgements: We would like to thank Françoise Bastié, Sylvie Cieply, Denny Dennis, Rob van Engelenburg, Mirjam Van Praag, Lex Van Teeffelen, and Lorraine Uhlaner for their helpful comments and Isabel Grilo and Jaime Silva of the European Commission and Agnes Illyes of Gallup Hungary for providing and explaining the data. The views expressed here are those of the authors and should not be attributed to the European Commission. This paper has been written in cooperation with the research program SCALES, carried out by EIM and financed by the Dutch Ministry of Economic Affairs. It benefitted from a grant by the 'Van Cappellen Stichting', and from Roy Thurik's short stay at Deutsches Institut für Wirtschaftsforschung (DIW) in Berlin. All authors contributed equally to the manuscript and are listed in alphabetical order.

\section{An update of the present paper has been accepted by Entrepreneurship Theory and Practice}


BUSINESS TAKEOVER OR NEW VENTURE? INDIVIDUAL AND ENVIRONMENTAL

\author{
DETERMINANTS FROM A CROSS-COUNTRY STUDY
}

\title{
INTRODUCTION
}

There are multiple ways to become an entrepreneur (Cooper \& Dunkelberg, 1986; Dennis, 1997). A clear distinction can be drawn between starting a new firm (new venture startup) and taking over an existing one (business takeover). The literature to date has extensively analyzed individual-level determinants of entrepreneurial choice (Grilo \& Thurik, 2008; Parker, 2009, chapter 4). Furthermore, many studies exist on the country-level drivers of entrepreneurship (Bowen \& De Clercq, 2008; Carree, Van Stel, Thurik, \& Wennekers, 2002; Parker \& Robson, 2004; Wennekers, Thurik, Van Stel, \& Noorderhaven, 2007). However, with a few exceptions (Bastié, Cieply, \& Cussy, in press; Parker \& Van Praag, 2012), researchers have been silent about the determinants of the mode of entry into entrepreneurship. This paper attempts to explain both individual-level and country-level differences in preferences for starting a new business rather than taking over an existing business.

The fact that only a few studies have focused on the mode of entry into entrepreneurship is surprising given its practical relevance for policy makers and entrepreneurs seeking to exit their businesses. From the perspective of existing enterprises, there is a considerable demand for entrepreneurs willing to take over existing businesses. Many business owners seek successors outside of their family or their business (Scholes, Wright, Westhead, Bruining, \& Kloeckner, 2009; Van Teeffelen, 2010). This demand for takeover candidates will most likely increase in the coming years as the population in many industrialized countries ages and many business owners approach retirement (Lévesque \& Minniti, 2011). The demographic change also affects the supply of potential entrepreneurs. That is, many investigations show an inverse U-shaped relationship between age and the decision to become an entrepreneur (Bönte, Falck, \& Heblich, 2009; Evans \& Leighton, 1989; Lévesque \& Minniti, 2006). The European Commission (2006 estimates that approximately one-third of European enterprises will require takeover in the next ten years. From the perspective of potential entrepreneurs, the preference for taking over an existing business is not much more uncommon: approximately $30 \%$ of potential entrepreneurs report that they prefer taking over an existing business to starting a new one (European Commission, 2003a). ${ }^{1}$ If incumbent business owners do not find successors for their businesses, the economic value of these businesses may be lost, with negative implications for employment, entrepreneurial experience, and economic growth. Policy initiatives may raise awareness of takeover opportunities and focus on creating a better match between potential buyers and sellers in marketplaces for business transfers.

Concerning the individual level, we argue that an individual's psychological characteristics influence the preferred mode of entry into entrepreneurship. New venture startups and business takeovers differ regarding their levels of business risk and inventiveness. Starting a business from scratch can be considered more entrepreneurial, more exciting, more complex, and riskier than taking over an existing business with an already-

\footnotetext{
${ }^{1}$ This percentage is approximately $20 \%$ in the United States. See Dennis (1997) in the 1995 Wells Fargo/NFIB series on business entries and exits.
} 
developed business model and an established customer base. Furthermore, prior research shows that entrepreneurs differ in their motivations and goals in starting a venture. In addition to financial aspects, there are a number of non-financial reasons to become an entrepreneur, including being independent or autonomous, having the opportunity to use one's skills and abilities and the nature of the work (Benz \& Frey, 2008; Block \& Koellinger, 2009; Hundley, 2001). Starting a business from scratch may be more rewarding in terms of these nonfinancial aspects. Research shows that substantial heterogeneity exists among entrepreneurs regarding, for example, risk attitude (Block, Sandner, \& Spiegel, in press; Caliendo, Fossen, \& Kritikos, 2010), innovation orientation (Cliff, Jennings, \& Greenwood, 2006; Koellinger, 2008), and human capital (Bosma, Van Praag, Thurik, \& De Wit, 2004; Shane, 2000). Along with these arguments, we propose that an individual's psychological factors, such as growth ambition, risk attitude and inventiveness, influence his/her preferred mode of entry into entrepreneurship.

Although entrepreneurial action is undertaken by individuals, the country context plays an inevitable role (Noorderhaven, Thurik, Wennekers, \& Van Stel, 2004; Shepherd, 2011; Uhlaner \& Thurik, 2007; Wennekers, Thurik, Van Stel, \& Noorderhaven, 2007). Relatively recently, scholars have begun to simultaneously analyze individual- and country-level influences on entrepreneurial activity by means of multi-level analyses (De Clercq, Lim, \& Hoon Oh, 2011; Stephan \& Uhlaner, 2010). Thus, this paper adopts a multi-level approach to analyze the country-level determinants of the preferred mode of entry into entrepreneurship. To this point, the literature has focused solely on individual-level determinants of the mode of entry (Bastié, Cieply, \& Cussy, in press; Parker \& Van Praag, 2012). We argue and show that substantial between-country variation exists in the preferred mode of entry. This paper tests the importance of several country-level variables in the explanation of this country-level variation. First, the administrative steps (and the time) required to set up a new business differ across countries (Djankov, La Porta, Lopez-de-Silanes, \& Shleifer, 2002; Grilo \& Irigoyen, 2006; Nicoletti \& Pryor, 2006). Therefore, in some countries more than in others, it is a rational choice to take over an existing business rather than to set up a new one. In addition to differences in administrative difficulties involved in setting up a business, a country's culture may also play a role. Some countries, such as Japan or South Korea, are known for their "no failure" culture (Begley \& Tan, 2001), which discourages an individual from beginning a new business rather than taking over an existing business that has already proven its success. Individuals may be hesitant to become entrepreneurs by means of new venture startups because this entry mode constitutes a choice associated with risk and uncertainty and a perceived high likelihood of failure. Finally, country-level variation in the preferred mode of entry into entrepreneurship may also depend on either differences in venture financing (Jeng \& Wells, 2000) or the level of innovation output (Furman, Porter, \& Stern, 2002). We posit that a higher availability of venture capital and bank loans should facilitate the financing of business takeovers, which often require extensive financing. Regarding a country's level of innovation output, we argue that countries with high levels of innovation output are characterized by capital-, knowledge-, and technology-intensive sectors, which makes new venture startups difficult.

To analyze the determinants of the preferred entry mode, our study uses a large international dataset covering all 27 member states of the European Union (EU), Croatia, Iceland, Norway, Switzerland, Turkey, the United States, China, Japan and South Korea. Hierarchical binomial and multinomial logistic regressions are performed to study the impacts of both individual-level variables and country-level variables on the preferred mode of entry. Our set of individual-level variables consists not only of psychological characteristics but certain socioeconomic characteristics (e.g., gender, age, education, occupational status) as 
well. Our sample includes both prospective and current business owners, i.e., individuals who are thinking about setting up a business, those who are actively taking steps to set up a business (nascent entrepreneurs), and existing business owners. The international focus distinguishes the present paper from existing studies on this under-researched but relevant topic.

The organization of this paper is as follows. The next section summarizes the existing literature regarding the determinants of the mode of entry into entrepreneurship. We observe a research gap and explain how the present paper contributes to filling this gap. The section also presents our arguments on how individual-level and country-level factors influence the preferred mode of entry. Subsequently, the data are discussed, followed by an overview of some basic descriptive statistics and a description of our multi-level analysis. The next section presents the regression results and robustness checks. In the final section, we discuss the results in light of the current literature, present limitations of this study and suggest avenues for further research.

\section{LITERATURE REVIEW AND THEORY DEVELOPMENT}

\section{Existing studies}

Whereas investigations of new ventures (de novo entrants or ex nihilo creations) are primarily found in the entrepreneurship literature, studies of takeovers are primarily found in the family business literature related to firm succession in family firms (Bennedsen, Nielsen, Pérez-González, \& Wolfenzon, 2007; Chua, Chrisman, \& Sharma, 2003; Molly, Laveren, \& Deloof, 2010). The successful transition of ownership and management within a family is central for conserving the family character of the business. However, in many cases, withinfamily succession is a desired, but not a feasible, option (Stavrou, 1999; Zellweger, Sieger, \& Halter, 2007), and a successor outside the family must be found. Given that individuals capable of taking over a business may also be capable of starting their own businesses, knowledge about what drives them to prefer one option over the other is crucial. Surprisingly, we found only two single-country studies focusing on this topic: Bastié, Cieply, \& Cussy (in press) and Parker \& Van Praag (2012).

Parker \& Van Praag (2012) investigate the decision takeover versus new venture startup for a representative sample of 709 Dutch entrepreneurs who have either taken over a business (from a family or a non-family member) or started a business from scratch. These authors focus on human capital in terms of years of schooling and consider several measures of experience (managerial, labor market, industry, and previous business) and family background (whether an individual was born into a business-owning family). The results reveal that education increases the likelihood of new venture startup versus business takeover, whereas a family business background and management experience are negatively associated with this likelihood. Parker \& Van Praag (2012) argue that individuals with more education are better able to recognize entrepreneurial opportunities (Shane, 2000; Ucbasaran, Westhead, $\&$ Wright, 2007) and thus are more likely to choose new venture startup as mode of entry. In addition, such individuals can cope better with the new and complex situation of developing a business from scratch. They are also in a better position to deal with the risk of starting a new business. In addition, Parker \& Van Praag (2012) note the alternative employment options available to highly educated individuals in the labor market (Nickel, 1979). Therefore, if the business fails, they have alternatives to which they can turn. Concerning the effect of the family business background, it is documented that individuals born into a family business 
already have a high probability of taking over that family business because within-family succession is the preferred option for many family business owners (Chua, Chrisman, \& Sharma, 2003; Miller, Steier, \& Le Breton-Miller, 2003).

Using a representative sample of more than 20,000 young French firms, some results of Bastié, Cieply, \& Cussy (in press) are in line with Parker \& Van Praag (2012). For example, managerial experience is associated with a higher likelihood of takeover versus new venture startup. In addition, education is positively associated with starting a new venture relative to taking over an existing business. However, according to Bastié, Cieply, \& Cussy (in press), individuals with entrepreneurs in their families or in their immediate social network are less likely to take over existing businesses than are other entrepreneurs. Furthermore, Bastié, Cieply, \& Cussy (in press) show that takeovers are more often financed by bank loans than are new startups.

\section{Individual-level determinants of mode of entry into entrepreneurship}

The process of starting a business from scratch differs from taking over an existing business in two major aspects. First, starting a new business can be considered riskier, and second, it can be considered more rewarding in terms of non-financial aspects of entrepreneurship. We will explain both aspects and how they relate to the individual determinants of the preferred mode of entry.

Starting a business from scratch can be regarded as a riskier and more uncertain endeavor than taking over an existing business. Hiring employees, creating an organizational structure and finding customers are all uncertain in nature. When taking over an existing business, the uncertainty and risk are clearly lower because the business has already survived the early startup phase in which the level of uncertainty and probability of failure are highest (Geroski, 1995). Prior research supports this argument. Bastié, Cieply, \& Cussy (in press), for example, explain the higher prevalence of receiving bank loans among takeovers by a different risk assessment of each mode of entry. That is, takeovers are considered less risky by banks because they have longer track records and are less opaque than new startups. Parker \& Van Praag (2012) analyze the variation in entrepreneurial income of either mode of entry. Their results show that, indeed, takeovers are associated with a lower variation in income relative to new venture startups and can therefore be considered the less risky option of the two modes of entry. In this study, we will argue that risk-averse individuals will seek business takeover as a mode of entry, whereas self-confident and risk-tolerant individuals will prefer a new venture startup. Existing research supports this suggestion. Bonin, Dohmen, Falk, Huffman, \& Sunde (2007) find that risk-averse individuals choose occupations with low earnings risks. A similar argument can be made for individuals with a more internal locus of control (Rotter, 1966). Individuals who perceive that they have a high level of control over aspects they can influence will feel more confident than other individuals in an uncertain situation. They are also better able to cope with the high uncertainty related to new venture startup as a mode of entry into entrepreneurship: a high level of internal locus of control should be associated with a new venture startup.

A new venture startup can be more rewarding than a business takeover, particularly in terms of the non-financial aspects of entrepreneurship. By starting a new business from scratch, entrepreneurs can shape the venture exactly as they want it to be. For example, they can decide which markets to enter, the exact product specifications and the composition of their venture teams. Additionally, entrepreneurs can design their own desired roles in the venture. For example, the entrepreneur may prefer to work part time (Folta, Delmar, \& 
Wennberg, 2010) or to engage in invention and product development (Åstebro, 2003). In sum, we expect the new venture option to score high in a number of non-financial aspects of entrepreneurship. Individuals who seek these non-financial rewards of entrepreneurship will be more likely to favor new venture startup over business takeover as an entry mode.

In addition to these psychological characteristics at the individual level, we will assess the influences of several socioeconomic characteristics. Some of these socioeconomic characteristics have been included in Bastié, Cieply, \& Cussy (in press) and Parker \& Van Praag (2012), including gender, age, years of schooling, and the parents' entrepreneurial background. Finally, occupational status and current business ownership are taken into account.

\section{Country-level determinants of mode of entry into entrepreneurship}

In addition to individual-level determinants, we will use four country-level determinants: culture, regulation, finance, and innovation output. Cultural factors may have an influence on the mode of entry into entrepreneurship. Research has shown sociocultural values to be an important part of the entrepreneurial environment, influencing entrepreneurial activity and performance. Beugelsdijk (2007) and Shane (1993) show that a country with a more "entrepreneurial" culture that is more open to risk taking relative to other countries will be more successful in originating innovations. Uhlaner \& Thurik (2007) conclude that postmaterialism as a cultural factor has an impact on a country's entrepreneurial activity. Potential entrepreneurs will assess their entrepreneurial behavior and performance against the moral rules of the society in which they start their firm. This evaluation process should be more important in countries with a collectivist culture. Noorderhaven, Thurik, Wennekers, \& Van Stel (2004) prove that dissatisfaction at the level of societies has a positive and significant influence on self-employment levels. Drawing on research on cultural differences among countries (Hofstede, 2001; House, Hanges, Javidan, Dorfman, \& Gupta, 2004), we suggest that potential entrepreneurs in East Asia are particularly sensitive to the judgment of the public regarding their success as entrepreneurs. Business failure will be associated with a far higher reputation loss in Japan and Korea than in other countries. Given the above arguments about the higher level of uncertainty associated with a new venture startup versus a business takeover, we expect respondents in more risk-averse countries such as Japan and Korea to be more in favor of business takeover compared with those in other countries. To illustrate this point, Ray (1994) quotes from a government committee report on entrepreneurship, which states that business failure will mean "castigation and ruin" for the entrepreneur.

In addition to the different cultural factors, countries may also differ in their regulations and institutions (Audretsch, Grilo, \& Thurik, 2007; Nicoletti \& Pryor, 2006) and in the administrative steps required to set up a new venture (Djankov, La Porta, Lopez-de-Silanes, \& Shleifer, 2002; Grilo \& Irigoyen, 2006; Levie \& Autio, 2011). Both the level of regulation and the administrative steps required to set up a business have an effect on entrepreneurship levels. Van Stel, Storey, \& Thurik (2007) show that minimum capital requirements and labor market regulations affect entrepreneurship rates, whereas administrative considerations seem to be unrelated to the decision to start a business. Levie \& Autio (2011) find that a lighter burden of regulation is associated with a higher number of strategic entrepreneurs and a higher relative prevalence of strategic entrepreneurial entry. Strategic entrepreneurs are defined as nascent or new entrepreneurs "who expect to employ 20 or more employees within five years" (Levie \& Autio, 2011, p. 1403). Comparing data from Spain (a heavily regulated economy) and Britain (a lightly regulated economy), Capelleras, Mole, Green, \& Storey 
(2008) show that newly registered firms in Britain start at a smaller size and grow more quickly than those in Spain. Thus, even though administrative considerations may not have an effect on entrepreneurship rates, the level of regulation may still have a considerable influence on how individuals start their businesses. In line with this argument, we posit that the level of administrative complexity required to set up a business influences the mode of entry into entrepreneurship. If the time and effort needed to set up a business are high, the relative attractiveness of taking over an existing business compared with starting a new one should increase. Potential entrepreneurs in countries with high levels of administrative and regulatory complexity should thus have higher business-takeover preferences compared with potential entrepreneurs in countries with low levels of administrative and regulatory complexity.

Taking over an existing business is associated with a higher capital requirement than starting up a new venture. Businesses available for takeover are already at a later stage in the venture cycle; accordingly, they should have a higher firm value relative to new ventures. In contrast, the creation of new ventures allows entrepreneurs to start small, with lower capital investment, and then grow step by step. Hence, a higher availability of bank or venture capital financing on a country level should facilitate the financing of takeovers and should be positively associated with takeover preferences. Moreover, because monitoring and selection costs are lower, many venture capital firms prefer later-stage to startup investments (Amit, Brander, \& Zott, 1998). Data from the annual yearbook of the European Private Equity and Venture Capital Association (EVCA) show that more than $90 \%$ of venture capital (VC) investment (by $\$$ value) is later-stage (European Private Equity and Venture Capital Association, 2011). A significant portion of VC funding goes to established firms as growth capital (e.g., mezzanine finance). Research from the finance literature differentiates between countries that are more capital market oriented (e.g., the United States and Britain) and those that are more bank oriented (e.g., Germany, Japan and France) (Antoniou, Guney, \& Paudyal, 2008). Analyzing the determinants of venture capital availability for a sample of 21 countries, Jeng \& Wells (2000) find that the importance of initial public offerings (IPOs) and private pension funds as well as labor market rigidities are significant determinants of venture capital availability. In line with Armour \& Cumming (2006), Jeng \& Wells also find that government policies can play an important role, in particular by establishing the regulatory environment and by initiating investments during economic downturns.

Considering a country's level of innovation output, research from industrial organization suggest that market entry is more difficult in countries characterized by high technological standards relative to other countries (Acemoglu, Aghion, \& Zilibotti, 2006; Yong \& Ho, 2006). Barriers to entry differ significantly across industries and markets and are determined by technology acquisition costs, the effectiveness of intellectual property rights, learning-based cost advantages, the existence of network effects, and other factors (Baumol, 1982; Geroski, 1995). New ventures suffer from the liability of small size (Aldrich \& Auster, 1986) and have difficulties entering markets characterized by high entry barriers. These difficulties discourage potential entrepreneurs from setting up their own venture and influence them toward business takeover. In summary, ceteris paribus, countries with more innovation output and higher technology standards should be associated with higher technology- and innovation-related entry barriers and thus higher takeover preferences relative to other countries. 


\section{DATA AND METHOD}

\section{Dataset}

We use the European Commission's Flash Eurobarometer Survey on Entrepreneurship (No. 283). The dataset consists of 26,168 randomly selected respondents aged 15 years and older of which the majority was contacted through telephone interviews between December 10, 2009 and January 16, 2010. ${ }^{2}$ The survey covers the 27 European Union Member States ${ }^{3}$, five other European countries (Croatia, Iceland, Norway, Switzerland, and Turkey), the United States, and China, Japan and South Korea. Three countries (Cyprus, Latvia, and Malta) were, however, excluded from the analysis due to missing data for some country-level variables.

The relevance of asking individuals about their preferred mode of entry into entrepreneurship may depend on the specific position of an individual in the entrepreneurial process. Our sample is a subset of the entire dataset and includes 5,650 individuals who are thinking about starting a business (potential entrepreneurs), are taking steps to start a business (nascent entrepreneurs), or own a business. These individuals have answered "yes" to one of the following four items in the questionnaire: "You are thinking about starting up a business" (potential entrepreneur), "You are currently taking steps to start a new business" (nascent entrepreneur), "You have started or taken over a business in the last three years which is still active today" (business owner), or "You have started or took over a business more than three years ago and it is still active" (business owner). After listwise deletion of missing values, our final sample consists of 4,210 individuals in 33 countries.

\section{Measures}

Dependent variable. An individual's preferred mode of entry is captured by the following question: "If you currently had the means to start your own business, including sufficient funding, would you rather set up a new one or take over an existing one?" Respondents may answer "take over an existing business," "set up a new one," or "none of these, not interested." From this question, we construct two dependent variables. The variable preferred mode of entry (two categories) equals 1 if the respondent prefers to take over an existing business and equals 0 if he/she prefers to set up a new one. Respondents who answered "none of these, not interested" are treated as missing values. This binary measure of preferred mode of entry is used in a hierarchical binomial logistic regression. The variable preferred mode of entry (three categories) adds a third category coded 2 for "none of these, not interested." Using these three possibilities for answers enables us to perform a hierarchical multinomial logistic regression to assess the influences of the individual-level and countrylevel variables on the preferred mode of entry.

\footnotetext{
${ }^{2}$ Face-to-face interviews were conducted in Bulgaria, the Czech Republic, Estonia, Hungary, Latvia, Lithuania, Poland, Romania, and Slovakia (approximately $30 \%$ of the total number of 26,168 interviews). In most countries, the target sample size amounts to 500 respondents. In Belgium, China, the Czech Republic, Germany, Greece, France, Hungary, Italy, Japan, the Netherlands, Poland, Portugal, South Korea, Spain, the United Kingdom, and the United States, the target sample size is 1,000 .

${ }^{3}$ Austria, Belgium, Bulgaria, Cyprus, the Czech Republic, Denmark, Estonia, Finland, France, Germany, Greece, Hungary, Ireland, Italy, Latvia, Lithuania, Luxembourg, Malta, the Netherlands, Poland, Portugal, Romania, Slovakia, Slovenia, Spain, Sweden, and the UK.
} 
Table 1 shows a detailed distribution of individuals across the three different answer categories of the dependent variable. Of the 5,375 individuals who give a valid response $(95 \%$ response rate), 1,431 (27\%) prefer a business takeover, 3,559 individuals (66\%) prefer a new venture startup, and 385 individuals (7\%) answer "none of these, not interested."

Individual level: socio-economic characteristics. In addition to gender (male $=1$; female $=0$ ) and age (at least 15 years), we also take into account educational attainment, captured by years of schooling. The measure is constructed as the age when the respondent finished full-time education, as given by the respondent, minus the assumed age of starting education (six years). For better comparison across countries, we constrain the minimum of years of schooling to nine years and the maximum to 19 years. Using the raw data, however, yields the same pattern of results. To reflect occupational status, we create dummy variables for individuals in white-collar professions, blue-collar professions, and for unemployed individuals seeking a job, coded 1 if the particular occupation applies to the respondent and 0 otherwise. White-collar professions include civil servants, office clerks, managerial positions, and professionals (examples of this last category are employed lawyers, accountants, architects, and doctors). Blue-collar professions are categorized as skilled manual workers, unskilled manual workers, or supervisors/foremen. A further breakdown of these blue-collar professions is not available. The group of civil servants (which includes public servants) is used as a reference group.

To consider possible role model effects, we create two variables, self-employed mother and self-employed father, coded 1 if $\mathrm{s} / \mathrm{he}$ is or was self-employed and 0 otherwise.

Finally, we take into account the level of the individual's entrepreneurial engagement: this variable takes a value of 1 if the individual is a current business owner and a value of 0 otherwise (if the individual is either thinking about or taking steps toward starting a business).

Individual level: psychological characteristics. We consider seven aspects of an individual's personality, each measured on a 4-point Likert scale (1="strongly disagree" to 4="strongly agree"): risk-taking propensity ("In general, I am willing to take risks"), selfconfidence ("Generally, when facing difficult tasks, I am certain that I will accomplish them"), internal locus of control ("My life is determined by my own actions, not by others or by chance"), proactiveness ("If I see something I do not like, I change it"), inventiveness ("I am an inventive person who has ideas"), optimism ("I am optimistic about my future"), and desire for competition ("I like situations in which I compete with others"). Finally, the following question is used to obtain a measure of growth aspiration: "Imagine that a friend of yours just started a business. Which advice would you give him or her?" Answer possibilities are "try to expand the business quickly" (value 1) or "grow slowly if at all" (value 0). The psychological variables rely on single-item measures, which is a limitation regarding meaningfulness. Yet, single-item measures also have advantages over multiple-item measures, e.g., regarding reductions in respondents' refusal rates or data collection costs (Bergkvist \& Rossiter, 2007; Nagy, 2002).

Country-level variables. At the country level, we control for GDP per capita (in purchasing power parities and US dollars). We expect that five variables on the dimensions of innovation, regulation, finance, and culture shape entry mode preferences. First, we take into account the level of innovation output in a country by means of the number of patents granted per million population in 2009. This information is retrieved from the Global Competitiveness Report (World Economic Forum, 2010). ${ }^{4}$ We use a logarithmically transformed version of

\footnotetext{
${ }^{4}$ To be precise, we have the availability of the number of "utility patents." As Fleming, Mingo, \& Chen (2007) observe: "Almost all U.S. patents are utility patents, while a small number are design patents, which protect a new, original and
} 
this innovation variable. Second, the administrative difficulty of starting a business (time needed) is measured in terms of the number of days required to set up a new business, as provided by the World Bank's (2011) Doing Business Database. A high value indicates that setting up a new business from scratch is administratively cumbersome, leading to higher takeover preferences in a country. Third, we suggest that the availability of bank loans impacts the preferred entry mode. This variable is again retrieved from the Global Competitiveness Report. It is based on experts' responses to the following question: "How easy is it to obtain a bank loan in your country with only a good business plan and no collateral?" Experts rate this question on a 7-point Likert-scale (1="impossible" to 7="very easy"). Fourth, as another financial indicator, the availability of venture capital is pulled from the Global Competitiveness Report. The question, "In your country, how easy is it for entrepreneurs with innovative but risky projects to find venture capital?" is assessed on the same 7-point Likert scale (1="impossible" to 7="very easy"). Fifth, a cultural aspect is taken into account. The variable country risk tolerance is obtained by extracting information from the present survey (Flash Eurobarometer Survey on Entrepreneurship, No. 283). The relevant statement is, "One should not start a business if there is a risk it might fail" (4-point Likertscale: 1 = "strongly agree" to $4=$ "strongly disagree"). Averaging this variable across respondents in a country results in a cultural variable that contains information on how individuals perceive risk taking in uncertain situations. Higher values indicate that respondents in a particular country are more risk-tolerant.

\section{Analysis}

Given that our individual-level data are nested within country-level data, hierarchical linear modeling (HLM; Rabe-Hesketh \& Skrondal, 2008; Raudenbush \& Bryk, 2002) is used with restricted maximum likelihood estimates. HLM examines each variable at the appropriate level of analysis (individual level or country level) and considers the interdependence among individuals within the same country (Hofmann, 1997). This approach avoids critical biases caused by the more traditional approach of aggregating or disaggregating nested data. Because our models propose main effects of country-level variables on individual-level outcomes (preference for a takeover rather than a new venture startup), we use the intercepts-as-outcomes model.

A necessary condition for such an analysis is sufficient between-country variation in the dependent variable. Table 2 presents the distribution of the preferred mode of entry across all countries. It reveals pronounced differences among Italy, Denmark, Spain, and Romania, where the takeover levels are below 20\%, and South Korea, Austria, Bulgaria, and Japan, where the levels are in excess of $40 \%$. An interesting distinction in Table 2 is the difference between Japan and South Korea, on one hand, and China, on the other hand. Whereas Japan and South Korea are among the countries in which starting from scratch is least attractive, Chinese respondents seem to prefer starting a new venture. A consistent pattern that describes the preferred entry mode among European countries is more difficult to unravel. Our multilevel analysis in the remainder of this paper is aimed at explaining these between-country differences.

To reduce potential multicollinearity and to render the intercept more interpretable, all individual-level predictors were centered around their group mean. The intercept, therefore, reflects the takeover decision of a respondent with a group average score on all individual-

ornamental design for a manufactured item, or plant patents, which protect a distinct and new variety of plant. Most social science research that uses patents only uses utility patents." 
level predictors (Hofmann, 1997). However, using uncentered data does not substantially alter our results.

Given the three outcomes of our dependent variable ("take over an existing business,, "set up a new one," or "none of these, not interested"), we use hierarchical generalized linear models (HGLM), more specifically, hierarchical multinomial logistic models. As in standard multinomial logistic regression, one reference category is assigned, which in our case is "set up a new one." Then, the individual-level coefficients for the two remaining categories ("take over an existing business" and "none of these/not interested") have to be interpreted relative to this reference category. In the remainder of this paper, we will focus on the comparison between "take over an existing business" and "set up a new one." Basically, positive coefficients imply that a higher value of a particular variable is associated with a higher likelihood that the preferred mode of entry is "take over an existing business" rather than "set up a new one." The country-level estimates are interpreted in a way similar to normal regression because the intercepts and slopes from the individual-level model are continuous and normally distributed.

As a robustness check, we also perform a hierarchical binomial logistic regression. In this alternative regression, our dependent variable takes value 0 when "set up a new one" is the preferred mode of entry and value 1 when "take over an existing business" is preferred.

\section{RESULTS}

Table 3 presents the mean and standard deviations of all individual-level and countrylevel variables, together with a correlation matrix. Computations of the variance inflation factor (VIF) reveal no serious threat of multicollinearity (VIF < 3.04).

The results of our hierarchical multinomial logistic regression analysis are displayed in Models 1 through 4 in Table 4. These models focus on the comparison between "take over an existing business" and "set up a new one." Regression results regarding the comparison between "none of these/not interested" and "set up a new one" are not given here but are available from the authors. Whereas Model 1 includes only the socioeconomic characteristics, Model 2 adds the psychological characteristics such that all individual-level variables are included in Model 2. Model 3 adds GDP per capita (the control variable at the country level), and Model 4 contains all individual-level and country-level variables.

\section{Individual-level determinants of the preferred mode of entry}

Focusing on the socioeconomic characteristics in Model 1, we do not find a significant relationship between gender and the preferred mode of entry $(\beta=-0.01 ; p>0.10)$. In other words, women and men do not differ in their preference for taking over a business versus starting a venture. Age, reflecting labor market experience to some extent, positively influences the preference for business takeover versus starting from scratch $(\beta=0.01 ; p<0.01)$. We also included an age-squared term in Model 1. This approach, however, did not improve the explanatory power and leads to non-significant coefficients of both the linear $(\beta=0.01$; $\mathrm{p}>0.10)$ and quadratic terms $(\beta=0.00 ; p>0.10)$. The number of years of schooling has a significant negative coefficient $(\beta=-0.04 ; p<0.01)$, implying that highly educated individuals prefer to start from scratch. This is in accordance with the findings of Parker \& Van Praag 
(2012), who argue that formal education is more useful in new venture startups than in business takeovers.

Furthermore, occupational status has some influence in that unemployed individuals prefer starting a new business $(\beta=-0.38 ; \mathrm{p}<0.01)$. However, we can find no significant difference between blue-collar and white-collar employees. The entrepreneurial background of the father seems to be more important in explaining the preferred mode of entry $(\beta=0.17$; $p<0.05)$ than the entrepreneurial background of the mother $(\beta=0.05 ; p>0.10)$. Finally, business owners as a group prefer a takeover more strongly than do the two other groups $(\beta=0.24 ; p<0.01 ;$ see also Table 1$)$.

Regarding an individual's personality, which is investigated in Model 2, we find that two characteristics are associated with a higher preference for starting a new business: risktaking propensity $(\beta=-0.15 ; p<0.01)$ and inventiveness $(\beta=-0.26 ; p<0.001)$. Contrary to our expectations, we find no significant impact from self-confidence, internal locus of control, proactiveness, optimism, desire for competition, or growth aspiration.

\section{Country-level determinants of the preferred mode of entry}

Model 3 adds GDP per capita $(\beta=-0.01 ; p>0.10)$, whereas Model 4 includes all countrylevel variables. The number of patents is positively associated with takeover preferences $(\beta=0.23 ; p<0.05)$; in other words, countries with a high level of innovation output are characterized by higher takeover preferences. The administrative burden of setting up a business also influences the preferred mode of entry: the amount of time required to set up a business in a country is positively related to the preference for taking over a business relative to starting from scratch $(\beta=0.02 ; p<0.05)$. Furthermore, the availability of bank loans has a significant positive relationship with the preferred mode of entry, albeit only weakly significant $(\beta=0.21 ; p<0.10)$, whereas the availability of venture capital has an insignificant coefficient $(\beta=0.21 ; p>0.10)$. Finally, there is a strong tendency to start from scratch rather than take over an existing business in risk-tolerant societies $(\beta=-1.29 ; p<0.001)$. A negative coefficient for country risk tolerance is consistent with our expectation that individuals in more risk-tolerant countries (i.e., countries with low risk aversion) are less likely to opt for takeover (thus are more likely to choose startup).

\section{Robustness checks and further analyses}

We conducted tests to check the robustness of our results. First, we omitted the category "none of these/not interested" of our dependent variable by treating its values as missing values and performed a hierarchical binary logistic regression (Models 5 through 8 in Table 4). When comparing Models 5 through 8 with Models 1 through 4, we find almost no differences regarding the outcomes of the individual-level variables. With respect to the country-level variables, we observe some small changes in the p-values. However, the pattern of our results did not change substantially. Indeed, results of the Hausman test (Hausman \& McFadden, 1984; detailed results available from the authors) show that the Independence of Irrelevant Alternatives (IIA) assumption is not violated in the multinomial logistic model. In other words, removing a particular category (in the case of Table 4, "none of these, not interested") does not lead to radical changes in the coefficients of the resulting categories in a binomial logistic regression. 
Second, we investigated whether our approach to treating missing values, listwise deletion, affected the results. ${ }^{5}$ Tests confirmed that data were missing at random; that is, the distribution of "missingness" was significantly related to other independent variables but not to the dependent variable. Thus, listwise deletion might distort findings, and imputing missing values by means of multiple imputation is typically recommended (Schafer \& Graham, 2002). We multiply imputed missing values 15 times, thereby increasing the individual-level sample size to 5,375 and 4,990 for the multinomial and binomial models, respectively. The combined results (available on request) do not substantially differ from our original results.

Third, we assessed the robustness of the coefficients of some individual-level and country-level determinants in Model 4 of Table 4. At the individual level, the positive impact of age could be partly attributed to a "wealth effect" because older people have higher incomes. An objective measure of income is not available. However, we add a perceived income variable, measured as individuals' responses to the question: "Which of the following phrases describes best your feelings about your household's income these days?" Our variables range from "find it very hard to manage on the present income" (value of 1) to "find it difficult to manage on the present income" (value is 2), "get by on the present income" (value is 3), and "live comfortably on the present income" (value is 4). The results show that age is again significant at $1 \%(\beta=0.01 ; \mathrm{p}<0.01)$, whereas the income variable does not have a significant impact $(\beta=0.03 ; p>0.10)$.

To rule out possible suppression effects between self-employed mother and selfemployed father, we excluded self-employed father from the analysis. This results again in an insignificant coefficient for self-employed mother $(\beta=0.15 ; \mathrm{p}>0.10)$. We also considered different combinations of both variables. That is, we created dummy variables for four situations: neither father nor mother self-employed (our reference group), father only selfemployed, mother only self-employed, or both father and mother self-employed. The findings are that "mother only self-employed" is again not significant $(\beta=-0.04 ; p>0.10)$ and "father only self-employed" is weakly significant $(\beta=0.16 ; p<0.10)$, whereas "both father and mother self-employed" is significant $(\beta=0.26 ; p<0.05)$. Thus, the effect is largest for those individuals with two self-employed parents.

Regarding the country level, our innovation output variable might be biased to large firms if these firms tend to patent more than smaller firms. We added a variable that controls for the industry structure in a country to Model 4 of Table 4, that is, the SME sector's share of formal employment in total employment when 250 employees is used as the cutoff point for the definition of SMEs (Ayyagari, Beck, \& Demirguc-Kunt, 2003). The result is that the number of patents retains its significance $(\beta=0.22 ; p<0.01)$, whereas the industry structure variable does not have any explanatory power $(\beta=0.01 ; p>0.10)$. Furthermore, the relatively high correlation (.75) between GDP per capita and number of patents leads us to perform two additional analyses. In each analysis, one of the two variables is omitted from the regression. The results are similar to those in Model 4 of Table 4 . The only noteworthy difference is that starting a business loses its significance when number of patents is omitted from the analysis.

\footnotetext{
${ }^{5}$ Overall, the number of missing values for the independent variables at the individual level is within a reasonable range, with a maximum of $9.2 \%$ for growth aspiration and all other variables below $3 \%$. This includes age $(0.3 \%)$, years of schooling $(2.9 \%)$, white-collar $(0.1 \%)$, blue-collar $(0.1 \%)$, unemployment $(0.1 \%)$, self-employed mother $(1.4 \%)$, selfemployed father $(2.2 \%)$, risk-taking propensity $(1.3 \%)$, self-confidence $(1.4 \%)$, internal locus of control $(1.7 \%)$, proactiveness $(2.3 \%)$, inventiveness (1.3\%), optimism (1.4\%), and desire for competition (1.6\%).
} 


\section{DISCUSSION AND CONCLUSIONS}

Firm turbulence is a major driver of economic growth (Schumpeter, 1942). Hence, determinants of entry and exit are at the forefront of scholarly analysis, but studies of modes of entry and exit are surprisingly few. The present paper addresses the question of whether (prospective) entrepreneurs prefer taking over an existing firm or starting a new venture. This is the first study that analyzes the mode of entry into entrepreneurship from an international perspective using data from 33 countries.

We found two single-country studies that investigate the actual (i.e., not preferred) mode of entry into entrepreneurship (Bastié, Cieply, \& Cussy, in press; Parker \& Van Praag, 2012). Earlier studies (Cooper \& Dunkelberg, 1986; Dennis, 1997) are of a more descriptive nature. The studies of Parker \& Van Praag (2012) and Bastié, Cieply, \& Cussy (in press) consider the results of preferences leading to intentions and actual behavior, whereas our study examines preferences leading to intentions. Thus any commonalities between our results and the results of Parker \& Van Praag (2012) and Bastié, Cieply \& Cussy (in press) may be related to the link between preferences and intentions, whereas differences may be related to the link between intentions and actual behavior (see also Van Praag \& Van Ophem (1995) and Grilo \& Irigoyen (2006)). As an example, like the two earlier studies, our study points to a positive relationship between education and starting a new venture versus taking over an existing one. Thus, it seems that the positive relationship between education and (actual) new venture startup can at least be explained by the link between preferences and the mode of entry intention. Beyond the effect of education, the present study finds that an individual's age increases takeover preferences, whereas psychological variables such as risktaking propensity and inventiveness lower this preference. The influences of these psychological variables on mode of entry decisions have not previously been addressed.

Our study adds an important element to the literature explaining differences in countrylevel entrepreneurship behavior (Audretsch, Thurik, Verheul, \& Wennekers, 2002; De Clercq, Lim, \& Hoon Oh, 2011; Djankov, La Porta, \& Lopez-de-Silanes, 2002; Parker, 2009; Stephan \& Uhlaner, 2010; World Bank, 2011). To this point, the literature has only analyzed the influence of country characteristics on the level of entrepreneurship activity. The mode of entry decision (i.e., the way individuals enter entrepreneurship) has received little attention. We find that innovation output and the administrative burden of setting up a new business are positively related to the preference for taking over an existing business. Furthermore, a country's risk tolerance is positively associated with the preference for starting a new business. From earlier research, we know that these country-level variables explain crosscountry differences in entrepreneurial engagement. The present study reveals that countrylevel variables on the dimensions of innovation, regulation, finance, and culture also influence the preferred mode of entry into entrepreneurship and, therefore, the distribution of new startups and takeovers in societies.

Policy documents stress the importance of the takeover option. For example, according to the European Commission (2003a), takeovers should be afforded the same importance as new venture startups in policy circles. Several proposals have been made to improve the business transfer environment, such as the reduction of taxes, measures to encourage timely preparation of those who want to sell their businesses and financial support for those who want to take over those businesses (European Commission, 2003a, 2003b, 2006). The extent of implementation of these measures differs among the EU member states (European Commission, 2003a). The aging population and recent increases in the proportion of business owners to the working population, combined with the positive effects of both phenomena on the preference for takeover, suggests that taking over a firm will increase in importance in the 
future. There seems to be a general feeling that the productivity slowdown in modern economies is attributable to low propensities to take risks and to invent. The entrepreneurial society seems to have stalled (Audretsch \& Thurik, 2001). If these propensities can be intensified by way of education or role models, higher proportions of new venture entries may be expected (given the negative influences of both individual-level risk taking and inventiveness on the preference for taking over an existing firm). Our results show that the result for risk tolerance can also be established at the aggregate level: individuals in societies with higher levels of risk tolerance (low risk aversion) display lower preferences for taking over a business on average. Thus, the individual level and the country level reinforce each other, and therefore the negative impact of risk aversion on new venture startup is further strengthened when the individual resides in a risk-averse society.

This study is not without limitations. Using data from the Flash Eurobarometer Survey on Entrepreneurship allows us to illuminate the effects of both individual- and country-level variables on the preferred entry mode. However, the survey relies on single-item measures to capture psychological characteristics, which limits the meaningfulness of self-reported responses. Future research could corroborate our findings by using multiple-item measurements. However, single-item measures have some advantages over multiple-item measures, such as reductions in respondents' refusal rates and a relatively low common methods bias (Bergkvist \& Rossiter, 2007; Nagy, 2002). Moreover, the effect of being a nascent entrepreneur versus being a potential entrepreneur on entry mode may suffer from survival bias. As we argued above, takeover is less risky than starting a venture from scratch, which is why the proportion of nascent entrepreneurs preferring a takeover rather than a new venture startup should be relatively high. It would be preferable to have longitudinal information concerning whether an individual was engaged in entrepreneurial activity in the past and whether this activity has been successful or not. Relatedly, it would be intriguing to learn more about firm survival and firm performance across both modes of entry. Again, a longitudinal design can help to answer these questions. The exact dynamics among preferences, intentions and actual behavior regarding the mode of entry play an important role and deserve to be explored in more detail. More suggestions for further research lie in modifications of existing measurements or in collecting new variables to be included in the analysis. At the individual level, one may be interested in the effect of specific entrepreneurship education (Von Graevenitz, Harhoff, \& Weber, 2010) on an individual's preferred mode of entry. The results can then help to modify the effectiveness of entrepreneurial education programs in terms of raising more awareness for the possibility of taking over an existing firm. It would also be important to learn more about whether the type of education (e.g., engineering- vs. business-related education) has an effect on mode of entry. At the country level, the current number of included countries implies a restriction on the number of variables that can be taken into account in the multi-level analysis. Many possibilities exist extending the cross-country analysis with further cultural variables, such as the collectivistic or individualistic nature of a society. Other dimensions of the regulatory regime regarding setting up a new business may also provide valuable insights to explain the large between-country variation in the preferred mode of entry. The present study takes into account only one dimension (time needed for setting up a business) originating from one source (World Bank, 2011). Finally, future research may also consider the ways in which investors are legally protected (La Porta, Lopez-de-Silanes, Shleifer, \& Vishny, 1998) or how bankruptcies of firms are handled (Armour \& Cumming, 2008). 


\section{REFERENCES}

Acemoglu, D., Aghion, P. \& Zilibotti, F. (2006). Distance to frontier, selection, and economic growth. Journal of the European Economic Association, 4(1), 37-74.

Amit, R., Brander, J. \& Zott, C. (1998). Why do venture capital firms exist? Theory and Canadian Evidence. Journal of Business Venturing, 13(6), 441-466.

Antoniou A., Guney Y. and Paudyal K. (2008): The determinants of capital structure: capital market-orientated versus bank-orientated institutions. Journal of Financial and Quantitative Analysis, 43(1), 59-92.

Armour, J. \& Cumming, D.J. (2006). The legislative road to Silicon Valley. Oxford Economic Papers, 58(4), 596-635.

Armour, J. \& Cumming, D.J. (2008). Bankruptcy law and entrepreneurship. American Law and Economics Review, 10(2), 303-350.

Åstebro, T. (2003). The return to independent invention: evidence of risk seeking, extreme optimism or skewness-loving? Economic Journal, 113(484), 226-239.

Audretsch, D.B., Grilo I. \& Thurik A.R. (eds.) (2007). The Handbook of Research on Entrepreneurship Policy. Cheltenham, UK and Northampton, MA, US: Edward Elgar Publishing Limited.

Audretsch, D.B. \& Thurik, A.R. (2001). What is new about the new economy: sources of growth in the managed and entrepreneurial economies, Industrial and Corporate Change, 10(1), 267-315.

Audretsch, D.B., Thurik, A.R., Verheul, I. \& Wennekers, S. (eds.) (2002). Entrepreneurship: Determinants and Policy in a European-US Comparison. Boston, MA, US and Dordrecht, Netherlands: Kluwer Academic Publishers.

Ayyagari, M., Beck, T., Demirguc-Kunt, A. (2003). Small and medium enterprises across the globe : a new database. World Bank. Policy Research Working Paper Series No. 3127.

Bastié F., Cieply, S. \& Cussy, P. (in press). The entrepreneur's mode of entry: the influence of social and financial capital. Small Business Economics, forthcoming, doi: 10.1007/s11187-011-9391-y.

Baumol, W.J. (1982). Contestable markets: An uprising in the theory of industry structure. American Economic Review, 72(1), 1-15.

Begley, T.M. \& Tan, W.-L. (2001). The socio-cultural environment for entrepreneurship: a comparison between East Asian and Anglo-Saxon Countries. Journal of International Business Studies, 32(3), 537-553.

Bennedsen, M.K., Nielsen, M.K., Pérez-González, F. \& Wolfenzon, D. (2007). Inside the family firm: the role of families in succession decisions and performance. Quarterly Journal of Economics, 122(2), 647-691.

Benz, M. \& Frey, B.S. (2008). The value of doing what you like: evidence from the selfemployed in 23 countries. Journal of Economic Behavior \& Organization, 68(3-4), 445455.

Bergkvist, L. \& Rossiter, J.R. (2007). The predictive validity of multiple-item versus singleitem measures of the same constructs. Journal of Marketing Research, 44, 175-184.

Beugelsdijk, S. (2007). Entrepreneurial culture, regional innovativeness and economic growth. Journal of Evolutionary Economics, 17(2), 187-210.

Block, J. \& Koellinger, P. (2009). I can't get no satisfaction-necessity entrepreneurship and procedural utility. Kyklos, 62(2), 191-209.

Block, J., Sandner, P., \& Spiegel, F. (in press). How do risk attitudes differ within the group of entrepreneurs: the role of motivation and procedural utility. Journal of Small Business Management, forthcoming. 
Bonin, H., Dohmen, T., Falk, A., Huffman, H. \& Sunde, U. (2007). Cross-sectional earnings risk and occupational sorting: the role of risk attitudes. Labour Economics, 14(6), 926937.

Bönte, W., Falck, O. \& Heblich, S. (2009). The impact of regional age structure on entrepreneurship. Economic Geography, 85(3), 269-287.

Bosma, N., Van Praag, M., Thurik, A.R. \& De Wit, G. (2004). The value of human and social capital investments for the business performance of startups. Small Business Economics, 23(3), 227-236.

Bowen, H.P. \& De Clercq, D. (2008). Institutional context and the allocation of entrepreneurial effort. Journal of International Business Studies, 39(4), 747-767.

Caliendo, M., Fossen, F. \& Kritikos, A. (2010). The impact of risk attitudes on entrepreneurial survival. Journal of Economic Behavior \& Organization, 76(1), 45-63.

Capelleras, J.C., Mole, K., Greene, F. \& Storey, D. (2008). Do more heavily regulated economies have poorer performing new ventures? Evidence from Britain and Spain. Journal of International Business Studies, 39(4), 688-704.

Carree, M.A., Van Stel, A. J., Thurik, A.R. \& Wennekers A.R.M. (2002). Economic development and business ownership: an analysis using data of 23 OECD countries in the period 1976-1996. Small Business Economics, 19(3), 271-290.

Chua, J.H., Chrisman, J.J. \& Sharma, P. (2003). Succession and nonsuccession concerns of family firms and agency relationships with nonfamily managers. Family Business Review, 16(2), 89-107.

Cliff, J.E., Jennings, P.D. \& Greenwood, R. (2006). New to the game and questioning the rules: the experiences and beliefs of founders who start imitative versus innovative firms. Journal of Business Venturing, 21(5), 633-663.

Cooper, A.C. \& Dunkelberg, W.C. (1986). Entrepreneurship and paths to business ownership. Strategic Management Journal, 7(1), 53-68.

De Clercq, D., Lim, D.S.K. \& Hoon Oh, C. (2011). Individual-level resources and new business activity: The contingent role of institutional context. Entreprenership Theory and Practice, forthcoming. doi: 10.1111/j.1540-6520.2011.00470.x.

Dennis, W.J. (1997). More than you think: an inclusive estimate of business entries. Journal of Business Venturing, 12(3), 175-196.

DeTienne, D.R. (2010). Entrepreneurial exit as a critical component of the entrepreneurial process: theoretical development. Journal of Business Venturing, 25(2), 203-215.

Djankov, S., La Porta, R., Lopez-de-Silanes, F. \& Shleifer, A. (2002). The regulation of entry. The Quarterly Journal of Economics, 117(1), 1-37.

European Commission (2003a). Transfer of businesses - continuity through a new beginning, final report of the MAP 2002 project. DG Enterprise, Brussels.

European Commission (2003b). Helping the transfer of businesses - a 'good practice guide' of measures for supporting the transfer of businesses to new ownership. DG Enterprise, Brussels.

European Commission (2006). Markets for business transfers - fostering transparent marketplaces for the transfer of business in Europe. DG Enterprise and Industry, Brussels.

European Private Equity and Venture Capital Association (2011). EVCA Yearbook 2011, http://www.evca.eu/uploadedfiles/Home/Knowledge_Center/EVCA_Research/Statistics/ Yearbook/Evca_Yearbook_2011.pdf.

Evans, D.S. \& Leighton, L.S. (1989). Some empirical aspects of entrepreneurship. American Economic Review, 79(3), 519-535.

Fleming, L., Mingo, S. \& Chen, D. (2007). Collaborative brokerage, generative creativity, and creative success. Administrative Science Quarterly, 52(3), 443-475. 
Folta, T.B., Delmar, F. \& Wennberg, K. (2010). Hybrid entrepreneurship. Management Science, 56(2), 253-269.

Furman, J.F., Porter, M.E. \& Stern, S. (2002). The determinants of national innovative capacity. Research Policy, 31(6), 899-933.

Geroski, P.A. (1995). What do we know about entry? International Journal of Industrial Organization, 13(4), 421-440.

Grilo, I. \& Thurik, A.R. (2008). Determinants of entrepreneurial engagement levels in Europe and the US. Industrial and Corporate Change, 17(6), 1113-1145.

Grilo, I. \& Irigoyen, J.M. (2006). Entrepreneurship in the EU. To wish and not to be. Small Business Economics, 26(4), 305-318.

Hausman, J. \& McFadden, D. (1984). Specification tests for the multinomial logit model. Econometrica, 52(5), 1219-1240.

Hofmann, D.A. (1997). An overview of the logic and rationale of hierarchical linear models. Journal of Management, 23(6), 723-744.

Hofstede, G. (2001). Culture's consequences: comparing values, behaviors, institutions and organizations across nations. Sage: Beverly Hills.

House, R., Hanges, P., Javidan, M., Dorfman, P. \& Gupta, V. (2004). Culture, leadership, and organizations: the Globe study of 62 societies. Sage: London.

Hundley, G. (2001). Why and when are the self-employed more satisfied with their work? Industrial Relations, 40(2), 293-317.

Jeng, L.A. \& Wells, P.C. (2000). The determinants of venture capital funding: evidence across countries. Journal of Corporate Finance, 6(3), 241-289.

Koellinger, P. (2008). Why are some entrepreneurs more innovative than others? Small Business Economics, 31(1), 21-37.

La Porta, R., Lopez-de-Silanes, F., Shleifer, A., \& Vishny, R. (1998). Law and finance. Journal of Political Economy 106(6), 1113-1155.

Lévesque, M. \& Minniti, M. (2006). The effect of ageing on entrepreneurial behavior. Journal of Business Venturing, 21(2), 177-194.

Lévesque, M. \& Minniti, M. (2011). Age matters: how demographics influence aggregate entrepreneurship. Strategic Entrepreneurship Journal, 5(3), 269-284.

Levie, J. \& Autio, E. (2011). Regulatory burden, rule of law, and entry of strategic entrepreneurs: an international panel study. Journal of Management Studies, 48(6), $1392-$ 1419.

Miller, D., Steier, L., \& Le Breton-Miller, I. (2003). Lost in time: intergenerational succession, change, and failure in family business. Journal of Business Venturing, 18(4), 513-531.

Molly, V., Laveren, E. \& Deloof, M. (2010). Family business succession and its impact on financial structure and performance. Family Business Review, 23(2), 131-147.

Nagy, M.S. (2002). Using a single-item approach to measure facet job satisfaction. Journal of Occupational and Organizational Psychology, 75(1), 77-86.

Nickel, S. (1979). Education and lifetime patterns of unemployment. Journal of Political Economy, 87(5), S117-S131.

Nicoletti, G. \& Pryor, F.L. (2006). Subjective and objective measures of governmental regulations in OECD nations. Journal of Economic Behavior \& Organization, 59(3), 433449.

Noorderhaven, N. Thurik, R., Wennekers, S., \& Van Stel, A. (2004). The role of dissatisfaction and per capita income in explaining self-employment across 15 European countries. Entrepreneurship: Theory and Practice, 28(5), 447-466. 
Parker, S.C. (2009). The Economics of Entrepreneurship. 2nd edition. Cambridge University Press: Cambridge.

Parker, S.C. \& Robson, M.T. (2004) Explaining international variations in self-employment: evidence from a panel of OECD. Southern Economic Journal, 71(2), 287-301.

Parker, S.C. \& Van Praag, M. (2012). The entrepreneur's mode of entry: business takeover or new venture start? Journal of Business Venturing, 27(1), 31-46.

Rabe-Hesketh, S. \& Skrondal, A. (2008). Multilevel and longitudinal modeling using Stata. College Station, Texas: Stata Press.

Raudenbush, S.W. \& Bryk, A.S. (2002). Hierarchical linear models: Applications and data analysis methods. $2^{\text {nd }}$ ed. Newbury Park et al.: Sage.

Ray, D.M. (1994). The role of risk taking in Singapore. Journal of Business Venturing, 9(2), 157-177.

Rotter, J.B. (1966). Generalized expectancies for internal versus external control of reinforcement. Psychological Monographs: General and Applied 80, Whole No. 609.

Schafer, J. L. \& Graham, J. W. (2002). Missing data: our view of the state of the art. Psychological Methods, 7(2), 147-177.

Scholes, L., Wright, M., Westhead, P., Bruining, H. \& Kloeckner, O. (2009). Family-firm buyouts, private equity, and strategic change. Journal of Private Equity, 12(2), 7-18.

Schumpeter, J. (1942). Capitalism, socialism and democracy. New York: Harper and Brothers.

Shane, S. (1993). Cultural influences on national rates of innovation. Journal of Business Venturing, 8(1), 59-73.

Shane, S. (2000). Prior knowledge and the discovery of entrepreneurial opportunities. Organization Science, 11(4), 448-469.

Shepherd, D.A. (2011). Multilevel entrepreneurship research: opportunities for studying entrepreneurial decision making. Journal of Management, 37(2), 412-420.

Stam, E., Thurik, A.R. \& Van der Zwan, P. (2010). Entrepreneurial exit in real and imagined markets. Industrial and Corporate Change, 19(4), 1109-1139.

Stavrou, E. (1999). Succession in family businesses: exploring effects of demographic factors on offspring intentions to join and take over the business. Journal of Small Business Management, 37(3), 43-61.

Stephan, U. \& Uhlaner, L. (2010). Performance-based vs. socially-supportive culture: a crossnational study of descriptive norms and entrepreneurship. Journal of International Business Studies, 41(8), 1347-1364.

Ucbasaran, D., Westhead, P. \& Wright, M. (2007). Opportunity identification and pursuit: does an entrepreneur's human capital matter? Small Business Economics, 30(2), 153-173.

Uhlaner, L. \& Thurik, A.R. (2007). Postmaterialism influencing total entrepreneurial activity across nations. Journal of Evolutionary Economics 17(2), 161-185.

Van Stel, A., Storey, D. \& Thurik, A. (2007). The effect of business regulations on nascent and young business entrepreneurship. Small Business Economics, 28(2), 171-186.

Van Praag, M. \& Van Ophem, H. (1995). Determinants of willingness and opportunity to start as an entrepreneur. Kyklos, 48(4), 513-540.

Van Teeffelen, L. (2010). Exploring success and failure in small firm business transfers. PhD thesis, Nyenrode Business University.

Von Graevenitz, G, Harhoff, D., \& Weber, R. (2010). The effects of entrepreneurship education. Journal of Economic Behavior \& Organization, 76(1), 90-112.

Wennberg K., Wiklund J., DeTienne D. \& Cardon M. (2010). Reconceptualizing entrepreneurial exit: divergent exit routes and their drivers. Journal of Business Venturing, 25(4), 361-375. 
Wennekers, S., Thurik, R., Van Stel, A. \& Noorderhaven N. (2007). Uncertainty avoidance and the rate of business ownership across 21 OECD countries, 1976-2004. Journal of Evolutionary Economics, 17(2), 133-160.

World Bank (2011). Doing Business. http://www.doingbusiness.org/custom-query.

World Economic Forum (2010). The Global Competitiveness Report 2010-2011. http://www3.weforum.org/docs/WEF_GlobalCompetitivenessReport_2010-11.pdf.

Yong, G. \& Ho, K. (2006). Innovation, imitation and entrepreneurship. Singapore Economic Review, 51(2), 147-173.

Zellweger, T., Sieger, P. \& Halter, F (2011). Should I stay or should I go? Career choice intentions of students with family business background. Journal of Business Venturing, 26(5), 521-536. 
Table 1. Percentages of takeover versus new venture across groups of respondents.

\begin{tabular}{|c|c|c|c|c|}
\hline Group of individuals & Takeover & New venture & $\begin{array}{r}\begin{array}{r}\text { None of } \\
\text { these/not } \\
\text { interested }\end{array} \\
\end{array}$ & Total \\
\hline \multirow[t]{2}{*}{ Thinking about entrepreneurship } & 531 & 1,568 & 91 & 2,190 \\
\hline & $24 \%$ & $72 \%$ & $4 \%$ & \\
\hline \multirow[t]{2}{*}{ Nascent entrepreneurs } & 215 & 756 & 20 & 991 \\
\hline & $22 \%$ & $76 \%$ & $2 \%$ & \\
\hline \multirow[t]{2}{*}{ Current business owners } & 685 & 1,235 & 274 & 2,194 \\
\hline & $31 \%$ & $56 \%$ & $12 \%$ & \\
\hline \multirow[t]{2}{*}{ Thinking + nascent + current business owners } & 1,431 & 3,559 & 385 & 5,375 \\
\hline & $27 \%$ & $66 \%$ & $7 \%$ & \\
\hline
\end{tabular}

Data source: Flash Eurobarometer Survey on Entrepreneurship, No. 283.

Note: Cyprus, Latvia, and Malta are excluded.

Table 2. Percentages of preferred mode of entry across countries.

\begin{tabular}{lccclccc}
\hline & \% T & \% N & \% NI & & \% T & \% N & \% NI \\
\hline Italy & 16 & 68 & 16 & Luxembourg & 26 & 71 & 3 \\
Denmark & 16 & 72 & 13 & Belgium & 27 & 56 & 16 \\
Spain & 17 & 76 & 7 & Estonia & 27 & 57 & 16 \\
Romania & 17 & 79 & 5 & Greece & 27 & 69 & 4 \\
Hungary & 20 & 69 & 12 & Norway & 28 & 66 & 6 \\
Ireland & 20 & 79 & 2 & Turkey & 28 & 70 & 2 \\
Croatia & 21 & 74 & 5 & Czech Republic & 29 & 56 & 15 \\
United Kingdom & 21 & 74 & 5 & Finland & 31 & 63 & 6 \\
France & 21 & 75 & 4 & Switzerland & 34 & 56 & 10 \\
United States & 21 & 76 & 3 & Lithuania & 36 & 59 & 5 \\
Portugal & 22 & 61 & 17 & Germany & 36 & 59 & 5 \\
Iceland & 22 & 69 & 9 & South Korea & 41 & 52 & 7 \\
Slovakia & 23 & 72 & 5 & Austria & 41 & 58 & 1 \\
Sweden & 24 & 62 & 14 & Bulgaria & 47 & 47 & 6 \\
Slovenia & 24 & 72 & 4 & Japan & 48 & 44 & 8 \\
Poland & 25 & 68 & 7 & & & & \\
China & 25 & 73 & 2 & & 27 & 66 & 7 \\
Netherlands & 26 & 67 & 7 & Total & & & \\
& & & & & & &
\end{tabular}

Data source: Flash Eurobarometer Survey on Entrepreneurship, No. 283;

Notes: T stands for "take over an existing business"; N stands for "set up a new business; NI stands for "none of these/not interested". Austria (83), Belgium (73), Croatia (73), Luxembourg (70), and Slovenia (82) are the only countries for which these percentages are based on less than 100 observations. Cyprus, Latvia, and Malta are excluded. 
Table 3. Means, standard deviations and correlations. ${ }^{a}$

\section{Variable}

Mean

SD

Individual-level variables

1. Preferred mode of entry ${ }^{\mathrm{b}}$ (three categories.)

2. Male

3. Age

4. Years of schooling

5. White-collar employee

6. Blue-collar employee

7. Unemployed

8. Self-employed mother

9. Self-employed father

10. Current business owner

11. Risk-taking propensity

12. Self-confidence

13. Internal locus of control

.46

SD

1

14. Proactiveness

15. Inventiveness

16. Optimism

17. Desire for competition

18. Growth aspiration

Country-level variables

19. GDP (ppp) per capita

20. Number of patents $(\log )$

21. Starting a business (time needed)

$.78-$

$\begin{array}{rrrr}.54 & .50 \quad .01 \\ 3.11 & 14.38 & .16 & .00\end{array}$

$\begin{array}{rrrr}14.38 & \mathbf{1 6} & .00 & - \\ 3.31 & -.04 & -.01 & .04\end{array}$

$\begin{array}{rrr}.16 & 3.31-.04-.01 & .04 \\ .30 & .46-.07-.07-.13 & .22\end{array}$

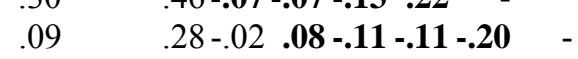

$.07 \quad .25-.07 \quad .02-.07-.04-.017-.08$

$.16 \quad .37 \quad .02-.03-.03-.05-.07-.05-.01$

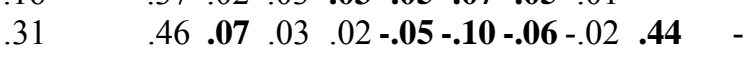

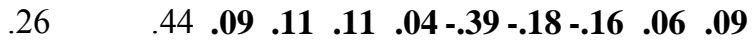

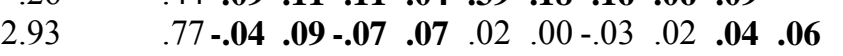

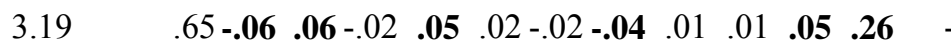

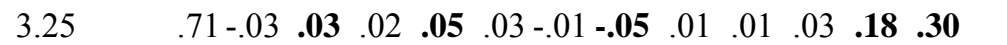

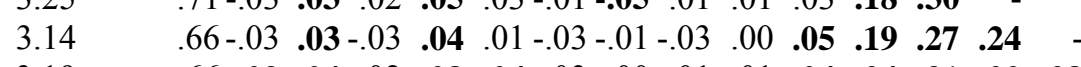

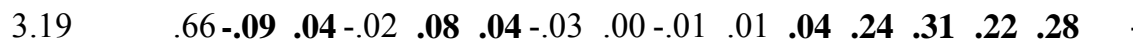

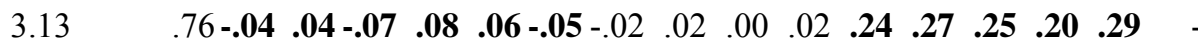

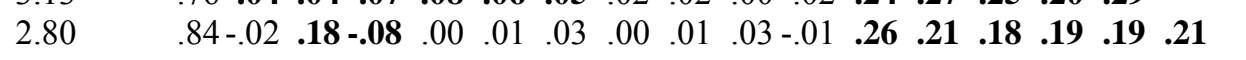

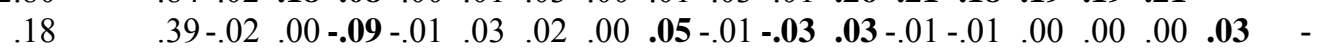

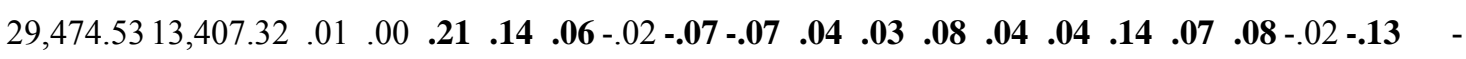

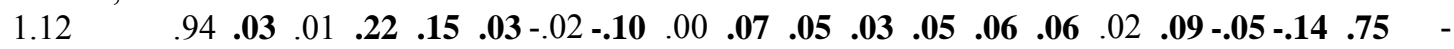

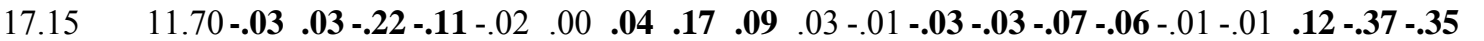

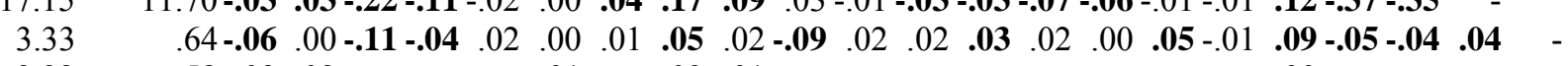

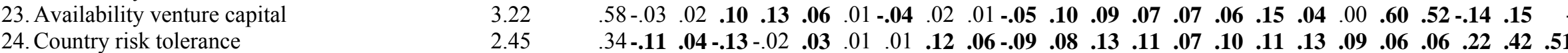

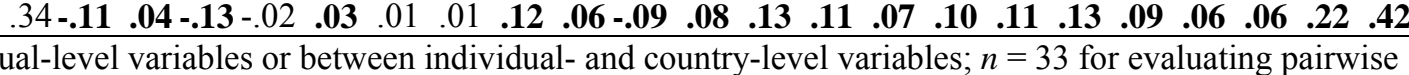

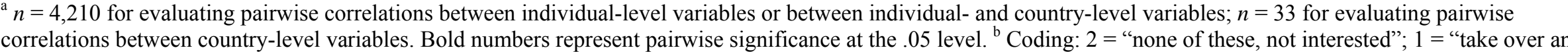
existing business"; $0=$ "set up a new one". 
Table 4. Regression results hierarchical multinomial and binomial logistic analysis. ${ }^{a}$

\begin{tabular}{|c|c|c|c|c|c|c|c|c|c|c|c|c|c|c|c|}
\hline \multirow[b]{3}{*}{ Variables } & \multicolumn{7}{|c|}{ Takeover vs. new business (multinomial model) } & \multicolumn{8}{|c|}{ Takeover vs. new business (binomial model) } \\
\hline & Model 1 & \multicolumn{2}{|c|}{ Model 2} & \multicolumn{2}{|l|}{ Model 3} & \multicolumn{2}{|c|}{ Model 4} & \multicolumn{2}{|c|}{ Model 5} & \multicolumn{2}{|l|}{ Model 6} & \multicolumn{2}{|c|}{ Model 7} & \multicolumn{2}{|l|}{ Model 8} \\
\hline & b s.e. & $\mathbf{b}$ & s.e. & $\mathbf{b}$ & s.e. & $\mathbf{b}$ & s.e. & $\mathbf{b}$ & s.e. & $\mathbf{b}$ & s.e. & $\mathbf{b}$ & s.e. & $\mathbf{b}$ & s.e. \\
\hline \multicolumn{16}{|c|}{ Individual level: socio-economic characteristics } \\
\hline Male & 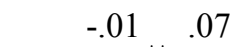 & .02 & .08 & .02 & .08 & .02 & .08 & -.02 & .07 & .01 & .07 & .01 & .07 & .01 & .07 \\
\hline Age & $.01^{* *} .00$ & $.01^{* *}$ & .00 & $.01^{* *}$ & .00 & $.01^{* *}$ & .00 & $.01^{\text {** }}$ & .00 & $.01^{* *}$ & .00 & $.01^{* *}$ & .00 & $.01^{* *}$ & .00 \\
\hline Years of schooling & $-.04^{* *} .01$ & $-.03^{*}$ & .01 & $-.03^{*}$ & .01 & $-.03^{*}$ & .01 & $-.03^{* *}$ & .01 & $-.03^{* *}$ & .01 & $-.03^{* *}$ & .01 & $-.03^{*}$ & .01 \\
\hline White-collar employee & $\begin{array}{ll}-.13 \quad .10\end{array}$ & -.11 & .10 & -.11 & .10 & -.11 & .10 & -.13 & .09 & -.11 & .09 & -.11 & .10 & -.11 & .10 \\
\hline Blue-collar employee & $.00 \quad .15$ & -.02 & .15 & -.02 & .15 & -.03 & .15 & .00 & .14 & -.02 & .14 & -.02 & .14 & -.02 & .15 \\
\hline Unemployed & $-.38^{* *} .14$ & $-.39^{*}$ & .17 & $-.39^{*}$ & .17 & $-.40^{*}$ & .18 & $-.36^{* *}$ & .13 & $-.38^{* *}$ & .13 & $-.38^{* *}$ & .13 & $-.38^{* *}$ & .14 \\
\hline Self-employed mother & $.05 * .12$ & .05 & .11 & .05 & .11 & .05 & .11 & $.05 *$ & .12 & $.05 *$ & .12 & .05 & .12 & $.05 *$ & .12 \\
\hline Self-employed father & $.17^{*} .08$ & $.19^{*}$ & .09 & $.19^{*}$ & .09 & $.19^{*}$ & .09 & $.16^{*}$ & .08 & $.18^{*}$ & .08 & $.18^{*}$ & .08 & $.19^{*}$ & .08 \\
\hline Current business owner & $.24^{* *} .09$ & $.29^{* *}$ & .10 & $.29^{* *}$ & .10 & $.29^{* *}$ & .10 & $.23^{*}$ & .09 & $.28^{* *}$ & .08 & $.28^{* *}$ & .08 & $.28^{* *}$ & .09 \\
\hline \multicolumn{16}{|c|}{ Individual level: psychological characteristics } \\
\hline Risk taking propensity & & $-.15^{* *}$ & .05 & $-.15^{* *}$ & .05 & $-.15^{* *}$ & .05 & & & $-.14^{* *}$ & .05 & $-.14^{* *}$ & .05 & $-.14^{*}$ & .06 \\
\hline Self-confidence & & -.09 & .06 & -.09 & .06 & -.09 & .06 & & & -.08 & .05 & -.08 & .05 & -.08 & .05 \\
\hline Internal locus of control & & .02 & .06 & .02 & .06 & .02 & .06 & & & .02 & .05 & .02 & .05 & .02 & .05 \\
\hline Proactiveness & & -.01 & .06 & -.01 & .06 & -.01 & .06 & & & -.01 & .05 & -.01 & .05 & -.01 & .06 \\
\hline Inventiveness & & $-.26^{* * *}$ & ${ }^{*} .06$ & $-.26^{* * *}$ & $* 06$ & $-.26^{* * *}$ & *.06 & & & $-.25^{* * *}$ & ${ }^{*} .04$ & $-.25^{* * *}$ & $* 04$ & $-.26^{* * *}$ & $* .04$ \\
\hline Optimism & & -.07 & .05 & -.07 & .05 & -.07 & .05 & & & $-.07^{\mathrm{t}}$ & .04 & $-.07^{\mathrm{t}}$ & .04 & -.07 & .05 \\
\hline Desire for competition & & .05 & .05 & .05 & .05 & .05 & .05 & & & .04 & .04 & .04 & .04 & .04 & .04 \\
\hline Growth aspiration & & .10 & .10 & .10 & .10 & .11 & .10 & & & .10 & .08 & .10 & .08 & .11 & .08 \\
\hline \multicolumn{16}{|l|}{ Country level } \\
\hline GDP (ppp) per capita & & & & -.01 & .00 & -.01 & .00 & & & & & -.01 & .00 & $-.01^{\mathrm{t}}$ & .00 \\
\hline Number of patents (log) & & & & & & $.23^{*}$ & .11 & & & & & & & $.23^{* *}$ & .06 \\
\hline Starting a business (time & & & & & & & & & & & & & & & \\
\hline needed) & & & & & & $.02^{*}$ & .01 & & & & & & & $.02^{\mathrm{t}}$ & .01 \\
\hline Availability of bank loans & & & & & & $.21^{\mathrm{t}}$ & .11 & & & & & & & $.20^{*}$ & .07 \\
\hline Availability of venture capital & & & & & & .21 & .17 & & & & & & & $.20^{\mathrm{t}}$ & .10 \\
\hline Country risk tolerance & & & & & & $-1.29^{* * *}$ & .30 & & & & & & & $-1.27^{* * *}$ & $* .21$ \\
\hline Deviance $(-2 * \log$ likelihood) & 11873.68 & 11824.74 & & 11824.65 & & 11803.40 & & 11873.68 & & 11824.68 & & 11824.61 & & 11803.15 & \\
\hline Deviance difference (Chi-sqr) & $66.66^{* * *}$ & $115.61^{* * *}$ & & $115.69^{* * *}$ & & $136.95^{* * *}$ & & $789.78^{* * *}$ & & $740.78^{*}$ & & $740.71^{*}$ & & $719.25^{* * *}$ & \\
\hline
\end{tabular}

${ }^{\text {a }}$ Models 1-4: Individual-level $n=4,210$; country-level $n=33$. Models 5-8: Individual-level $n=3,849$; country-level $n=33$. Robust standard errors are reported.

${ }^{\mathrm{t}} \mathrm{p}<.10,{ }^{*} \mathrm{p}<.05,{ }^{* *} \mathrm{p}<.01,{ }^{* * *} \mathrm{p}<.001$ (two-tailed test). 


\section{Publications in the ERIM Report Series Research* in Management}

\section{ERIM Research Program: "Organizing for Performance"}

2010

Investigating the Perceptions of Credit Constraints in the European Union

Erik Canton, Isabel Grilo, Josefa Monteagudo, and Peter van der Zwan

ERS-2010-001-ORG

http://hdl.handle.net/1765/17699

Two Lighthouses to Navigate: Effects of Ideal and Counter-Ideal Values on Follower Identification and Satisfaction with their Leaders

Niels van Quaquebeke, Rudolf Kerschreiter, Alice E. Buxton, and Rolf van Dick

ERS-2010-003-ORG

http://hdl.handle.net/1765/17702

Genome-wide Association Studies and the Genetics of Entrepreneurship

Matthijs J.H.M. van der Loos, Philipp D. Koellinger, Patrick J.F. Groenen, and A. Roy Thurik

ERS-2010-004-ORG

http://hdl.handle.net/1765/17757

How embodied cognitions affect judgments: Height-related attribution bias in football foul calls

Niels van Quaquebeke and Steffen R. Giessner

ERS-2010-006-ORG

http://hdl.handle.net/1765/17827

Flexible Labor and Innovation Performance: Evidence from Longitudinal Firm-Level Data

Haibo Zhou, Ronald Dekker, and Alfred Kleinknecht

ERS-2010-007-ORG

http://hdl.handle.net/1765/18037

The Influence of Installed Technologies on Future Adoption Decisions: Empirical Evidence from E-Business

Philipp Koellinger and Christian Schade

ERS-2010-012-ORG

http://hdl.handle.net/1765/18463

Seeds of Regional Structural Change: The Role of Entrepreneurs and Expanding Firms in Shaping Local Path Dependencies

Frank Neffke and Martin Henning

ERS-2010-014-ORG

http://hdl.handle.net/1765/19207

Determinants of Contractual Completeness in Franchising

George Hendrikse and Josef Windsperger

ERS-2010-017-ORG

http://hdl.handle.net/1765/19424

Agglomeration and New Establishment Survival: A Mixed Hierarchical and Cross-Classified Model

Martijn J. Burger, Frank G. van Oort, and Otto Raspe

ERS-2010-018-ORG

http://hdl.handle.net/1765/19519

Corporate Social Responsibility in Large Family and Founder Firms

Joern Block and Marcus Wagner

ERS-2010-027-ORG

http://hdl.handle.net/1765/20273 
The Social Capital of Venture Capitalists and Its Impact on the Funding of Start-Up Firms

Oliver Alexy, Joern H. Block, Philipp Sander, and Anne L.J. Ter Wal

ERS-2010-028-ORG

http://hdl.handle.net/1765/20274

House Prices, Bubbles and City Size

Mark J.P.M. Thissen, Martijn J. Burger, and Frank G. van Oort

ERS-2010-030-ORG

http://hdl.handle.net/1765/20380

Drivers of Sales Performance: A Contemporary Meta-Analysis

Willem Verbeke, Bart Dietz, and Ernst Verwaal

ERS-2010-031-ORG

http://hdl.handle.net/1765/20379

The Geography of Equity Listing and Financial Centre Competition in Mainland China and Hong Kong

Bas Karreman, and Bert van der Knaap

ERS-2010-033-ORG

http://hdl.handle.net/1765/20447

Business Takeover or New Venture? Individual and Environmental Determinants from a Cross-Country Study Joern Block, Roy Thurik, and Peter van der Zwan

ERS-2010-042-ORG

http://hdl.handle.net/1765/21239

* A complete overview of the ERIM Report Series Research in Management: https://ep.eur.nl/handle/1765/1

ERIM Research Programs:

LIS Business Processes, Logistics and Information Systems

ORG Organizing for Performance

MKT Marketing

F\&A Finance and Accounting

STR Strategy and Entrepreneurship 